\title{
FIXED POINT THEOREMS FOR VARIOUS TYPES OF $F$-CONTRACTIONS IN COMPLETE $b$-METRIC SPACES
}

\author{
A. LUKÁCS* AND S. KAJÁNTÓ** \\ *Department of Mathematics and Computer Science, Babeş-Bolyai University \\ M. Kogălniceanu street No. 1, RO-400084, Cluj-Napoca, Romania \\ E-mail: lukacs.andor@math.ubbcluj.ro \\ ${ }^{* *}$ Department of Mathematics and Computer Science, Babeş-Bolyai University \\ M. Kogălniceanu street No. 1, RO-400084, Cluj-Napoca, Romania
}

Abstract. We generalize various types of $F$-contractions defined by Wardowski, Vetro and others to $b$-metric spaces and prove fixed point theorems for them. The examples given show that these generalizations extend the existing results in a significant way.

Key Words and Phrases: $F$-contractions, $b$-metric spaces, fixed point theorems.

2010 Mathematics Subject Classification: 47H09, 47H10, 54E50, 54H25.

Acknowledgements. Both authors were supported by a grant of the Talent Support Council of Transylvania, project number NTP-HTT-M-16-0004. The second author was supported by Babeş-Bolyai University through a Performance Grant. The authors would also like to thank the referee for his valuable observations and comments, which improved both the exposition and the results of the paper.

\section{REFERENCES}

[1] H.H. Alsulami, E. Karapinar, H. Piri, Fixed points of generalised F-Suzuki type contraction in complete b-metric spaces, Discrete Dynamics in Nature and Society, 2015, 8 pages.

[2] H. Aydi, M.F. Bota, E. Karapinar, S. Mitrović, A fixed point theorem for set-valued quasicontractions in b-metric spaces, Fixed Point Theory Appl., 88(2012), 8 pages.

[3] H. Aydi, M.F. Bota, E. Karapinar, S. Moradi, A common fixed point for weak $\phi$-contractions on b-metric spaces, Fixed Point Theory, 13(2012), no. 2, 337-346.

[4] M.F. Boriceanu, M. Bota, A. Petruşel, Multivalued fractals in b-metric spaces, Cent. Eur. J. Math., 8(2010), no. 2, 367-377.

[5] C. Chifu, G. Petruşel, Fixed points for multivalued contractions in b-metric spaces with application to fractals, Taiwanese J. Math., 18(2014), no. 5, 1365-1375.

[6] L.B. Ćirić, A generalization of Banach's contraction principle, Proc. Amer. Math. Soc., 45(1974), 267-273.

[7] M. Cosentino, M. Jleli, B. Samet, C. Vetro, Solvability of integrodifferential problems via fixed point theory in b-metric spaces, Fixed Point Theory Appl., 70(2015), 15 pages.

[8] M. Cosentino, P. Vetro, Fixed point results for F-contractive mappings of Hardy-Rogers-type, Filomat, 28(2014), no. 4, 715-722.

[9] S. Czerwik, Contraction mappings in b-metric spaces, Acta Math. Inform. Univ. Ostraviensis, 1(1993), 5-11. 
[10] G.E. Hardy, T.D. Rogers, A generalization of a fixed point theorem of Reich, Canad. Math. Bull., 16(1973), no. 2, 201-206.

[11] W. Kirk, N. Shahzad, Fixed Point Theory in Distance Spaces, Springer International Publishing Switzerland, 2014.

[12] S. Reich, Some remarks concerning contraction mappings, Canad. Math. Bull., 14(1971), no. $1,121-124$.

[13] I.A. Rus, M.A. Şerban, Basic problems of the metric fixed point theory and the relevance of a metric fixed point theorem, Carpathian J. Math., 29(2013), no. 2, 239-258.

[14] T. Suzuki, A generalized Banach contraction principle that characterizes metric completeness, Proc. Amer. Math. Soc., 136(2008), 1861-1869.

[15] D. Wardowski, Fixed points of a new type of contractive mappings in complete metric spaces, Fixed Point Theory and Applications, 94(2012), 6 pages.

[16] D. Wardowski, Fixed points of F-weak contractions on complete metric spaces, Demonstratio Math., 47(2014), no. 1, 146-155.

Received: October 23, 2015; Accepted: February 1, 2017. 
